\title{
Loss- and gain-of-function analysis of the lipid raft proteins Reggie/Flotillin in Drosophila: They are posttranslationally regulated, and misexpression interferes with wing and eye development
}

\author{
Martin Hoehne, ${ }^{\mathrm{a}}$ H. Gert de Couet, ${ }^{\mathrm{a}, \mathrm{b}}$ Claudia A.O. Stuermer, ${ }^{\mathrm{c}}$ and Karl-Friedrich Fischbach ${ }^{\mathrm{a}, *}$ \\ anstitut für Biologie III, Schänzlestr.1, 79104 Freiburg, Germany \\ ${ }^{\mathrm{b}}$ Department of Zoology, University of Hawaii, 2538 McCarthy Mall, Honolulu, HI 96822, USA \\ ${ }^{\mathrm{c}}$ Dept. Biology, University of Konstanz, 78457 Konstanz, Germany
}

\begin{abstract}
Reggie/Flotillin proteins are upregulated after optic nerve dissection and evolutionary highly conserved components of lipid rafts. Whereas many biochemical and cell culture studies suggest an involvement in the assembly of multiprotein complexes at cell contact sites, not much is known about their biological in vivo functions. We therefore set out to study the expression pattern and the effects of loss- and gain-offunction in the Drosophila melanogaster model system. We found that in flies these proteins are mainly expressed in axons at the root of fiber tracts, in places where strong fasciculation is required, e.g. at the neck of the peduncle of the mushroom bodies and in the optic chiasms. Despite their evolutionary conservation which implies fundamental and important functions, a P-element-induced null mutant (KG00210) of reggie1/flotillin2 (reggie1/flo2) in D. melanogaster shows no apparent phenotypic defects. This was even more surprising as we show that in this reggie1/flo2 null mutant the paralogous Reggie2/Flo1 protein is unstable and degraded, while the transcript is still present. The requirement of Reggie1/Flo2 for Reggie2/Flo1 stabilization is confirmed by misexpression experiments. Reggie2/Flo1 can only be misexpressed when Reggie1/Flo2 is provided as well. Conversely, Reggie1/Flo2 immunoreactivity can be detected, when its transgene is misexpressed alone. Using appropriate Gal4 driver lines, misexpression of Reggie1/Flo2 alone or together with Reggie2/Flo1 in the eye imaginal disc results in a specific and severe mislocalization of cell adhesion molecules of the immunoglobulin superfamily (IgCAMs) (while DECadherin is unaffected) and in differentiation defects pointing to impaired signaling. In the wing imaginal disc, global overexpression of Reggie/Flotillin proteins leads to a significant extension of the Wingless signal and severely disrupts normal wing development. Our data support the notion that Reggie/Flotillin proteins are implicated in signaling processes at cellular contact sites.
\end{abstract}

\footnotetext{
* Corresponding author.

E-mail address: kff@uni-freiburg.de (K.-F. Fischbach).
}

\section{Introduction}

Lipid rafts are detergent resistant membrane (DRM) micro domains of distinct lipid and protein composition, which is reflected by the insolubility of DRM/raft proteins in nonionic detergents. Raft/DRM proteins promote the aggregation and interaction of specific sets of proteins and contribute to the spatial and temporal control of signaling processes (reviewed in Simons and Toomre, 2000; Tsui Pierchala et al., 2002; Benzing, 2004). Moreover, DRM/lipid rafts are involved in vesicle trafficking, protein sorting and phagosome biogenesis (Zajchow ski and Robbins, 2002; Golub et al., 2004; Helms and Zurzolo, 2004).

Certain DRM/raft microdomains depend on specific scaffolding proteins. Caveolin, for instance, is responsible for the formation of caveolae, whereas stomatins, Podocin and Reggie 1 and 2 (Schulte et al., 1997; Lang et al., 1998) also known as Flotillin 2 and 1, respectively (Bickel et al., 1997) are respon sible for the formation of non caveolar flat DRM/rafts (Stuermer et al., 2001). They were initially identified as a pair of closely related proteins in a screen for antigens that are upregulated in retinal ganglion cells with regenerating axons in the goldfish after optic nerve transection (Schulte et al., 1997) and therefore named Reggie 1 and Reggie 2.

Both Reggie/Flotillin proteins are evolutionarily highly con served and exist in most animals, including humans (Bickel et al., 1997; Galbiati et al., 1998; Malaga Trillo et al., 2002). Homologous proteins also exist in procaryotes and plants which suggests an important and ancient role in cellular development and maintenance (Stuermer and Plattner, 2005). In vertebrates, Reggies/Flotillins are most strongly expressed in the nervous system (Bickel et al., 1997; von Philipsborn et al., 2005). Reggies/Flotillins are present in a multitude of cells in culture (Volonte et al., 1999; Stuermer et al., 2001; Rajendran et al., 
2003) and are consistently enriched in the DRM/lipid raft fraction (Bickel et al., 1997; Rajendran et al., 2003; Deininger et al., 2003; Stuermer et al., 2004). Moreover, Reggies/Flotillins oligomerize (Neumann Giesen et al., 2004) to form microdomain scaffolds (Stuermer and Plattner, 2005) for the spatial assembly of certain GPI anchored and transmembrane proteins and for communication with intracellular signal transducing molecules (Stuermer et al., 2001; Stuermer et al., 2004) much like Caveolin or Podocin.

Compelling evidence for the morphogenetic function of DRM scaffolding proteins has been found in the kidney. The kidney slit diaphragm is dependent on the ordered arrangement of Ig superfamily proteins, Neph and Nephrin, which possess large intracellular domains involved in the communication with Podocin and additional signaling molecules on the cytoplasmic face of the plasma membrane (Benzing, 2004). It was shown that Podocin contributes to the formation of this highly specialized DRM domain which enables Neph and Nephrin to interact along and across foot processes. Mutations in the Podocin encoding gene (Boute et al., 2000) lead to severe kidney dysfunction caused by the absence of the slit diaphragm.

Furthermore, Reggie/Flotillin proteins appear to coordinate the assembly of multiprotein complexes in certain cellular domains (Stuermer et al., 2001, 2004). For example, Reggies/Flotillins cluster at cell contact sites in vivo and in vitro (Stuermer and Plattner, 2005) and are upregulated in mouse fibroblast cell cultures with increasing confluency (Lopez Casas and del Mazo, 2003). They pattern the activation zone in lymphocytes, the cap, and represent platforms for the assembly of cell surface proteins such as Thy 1, F3 and $\operatorname{PrP}^{\mathrm{c}}$ (Stuermer et al., 2001, 2004). Reggies/Flotillins thus seem to participate in cell recognition and adhesion (von Philipsborn et al., 2005; Harris and Siu, 2002) probably through the coordination of the relevant cell adhesion/ recognition molecules and intracellular signaling molecules (Stuermer and Plattner, 2005). Emerging evidence suggests further that Reggies/Flotillins communicate with the actin cytoskeleton (Kioka et al., 2002; Neumann Giesen et al., 2004; Stuermer et al., 2004).

In the present study, we applied contemporary genetic techniques in combination with conventional cell biological methods to investigate the role of Reggie/Flotillin proteins in Drosophila. Available data indicate that Drosophila reggie2/flo1 mRNA is predominantly expressed in the embryonic nervous system (Galbiati et al., 1998). We show here that Reggie/ Flotillin proteins are also strongly expressed in neural tissues and that this expression is restricted to specific axonal sites. We furthermore demonstrate that Drosophila Reggies/Flotillins partition into the DRM/lipid raft fraction of embryonic membranes.

A null mutant for reggiel/flo2 is viable and lacks a detectable external or internal mutant phenotype. This was surprising since we could show that this mutant is also depleted of Reggie2/Flo1 protein, whereas the transcript is still present. The Reggie2/Flo1 protein can furthermore only be misexpressed together with Reggie1/Flo2. We used misexpres sion of Reggies/Flotillins to study the interference with lipid raft/DRM domain dependent functions during imaginal disc development. Our data show that Reggies/Flotillins interfere with the distribution of cell adhesion and signaling molecules in imaginal discs.

\section{Results}

Structure and expression of Drosophila Reggie/Flotillin genes

The Drosophila genome contains two unlinked Reggie/Flotillin genes on chromosomes I (flo2; 12F5 13A1) and II (flo1, 52B1

2) which are orthologous to vertebrates reggiel and reggie2, respectively. Western blot and RT PCR analysis demonstrate that transcripts and translation products of both paralogues are expressed during all developmental stages of the fly. Extensive database analysis identified two reggiel/flo2 EST populations, differing in 39 additional base pairs genomically encoded by a short exon. These transcripts represent the splice form reggielb/ $f l o 2 b$, as opposed to the shorter reggiela/flo $2 a$ form. Alternative splicing has not been reported in reggie/flotillins from other species, and the amino acid sequence encoded by this exon appears to represent an insertion specific to Drosophila (Fig. 1A). Furthermore, we showed the expression of both splice variants throughout development by RT PCR analysis (Figs. 1B, C). Comparison between the expression levels of both splice variants revealed that reggielb/flo $2 b$ is strongly expressed during embry onic and larval development, whereas reggiela/flo2a predomi nates in adult flies (Fig. 1C). Developmental Western blot analysis with Reggie specific antibodies also showed the expression of both reggie/flotillin genes throughout all developmental stages (Figs. 1D, E).

This expression pattern is consistent with in situ hybridization results reported previously (Galbiati et al., 1998). During later developmental stages, both Reggies/Flotillins show a complex expression pattern in the optic lobes and central brain (Fig. 2C) where antibody staining is restricted to axon fascicles. Expression was strongest in regions where axons or axon bundles from different directions join each other. This is particularly evident in the mushroom body (MB) (Fig. 2D), a paired structure in the insect central brain that plays an important role in higher order sensory integration and learning (Ito et al., 1997; Zars, 2000). Each of the two Drosophila MBs consists of about 2500 neurons called Kenyon cells (Ito et al., 1997) which are the descendants of four neuroblasts and which accordingly form four separate clusters. Labeling by anti Reggie/Flotillin antibodies is only observed where axons of the Kenyon cells from each cluster fasciculate and project into the peduncle (Fig. 2D). In the optic lobes, fiber tracts between the neuropils were labeled, but not the synaptic regions of the neuropils. Labeled fiber tracts comprise the outer and the inner optic chiasm and the neck of the fiber tracts connecting the lobula with the central brain (Figs. 2E, F). The serpentine layer in the medulla contains axons of large tangential neurons, which are weakly labeled (Figs. 2E, F). Reggie/Flotillin expression is clearly neuronal (as opposed to glial) as is exemplified in the optic chiasm of adult flies, where anti Reggie/ Flotillin antibodies label the axon tracts and not the glial cells (Figs. 2G I).

KG00210 is a null mutant for Reggie1/Flo2 and is in addition depleted of Reggie2/Flo1

Based on the structural conservation, complex expression patterns and the developmental regulation, we expected to find phenotypic disturbances in reggie/flotillin loss of function or overexpression mutants. However, database surveys initially revealed no known mutant alleles for either Reggie1/Flo2 or 
A
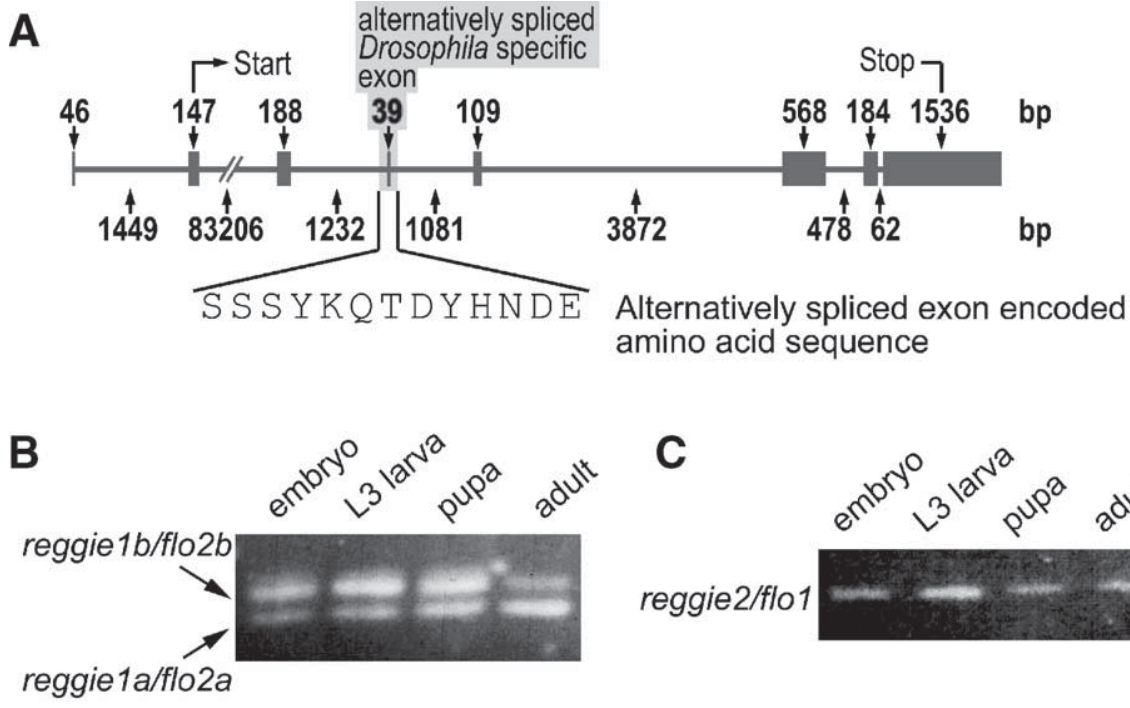

C
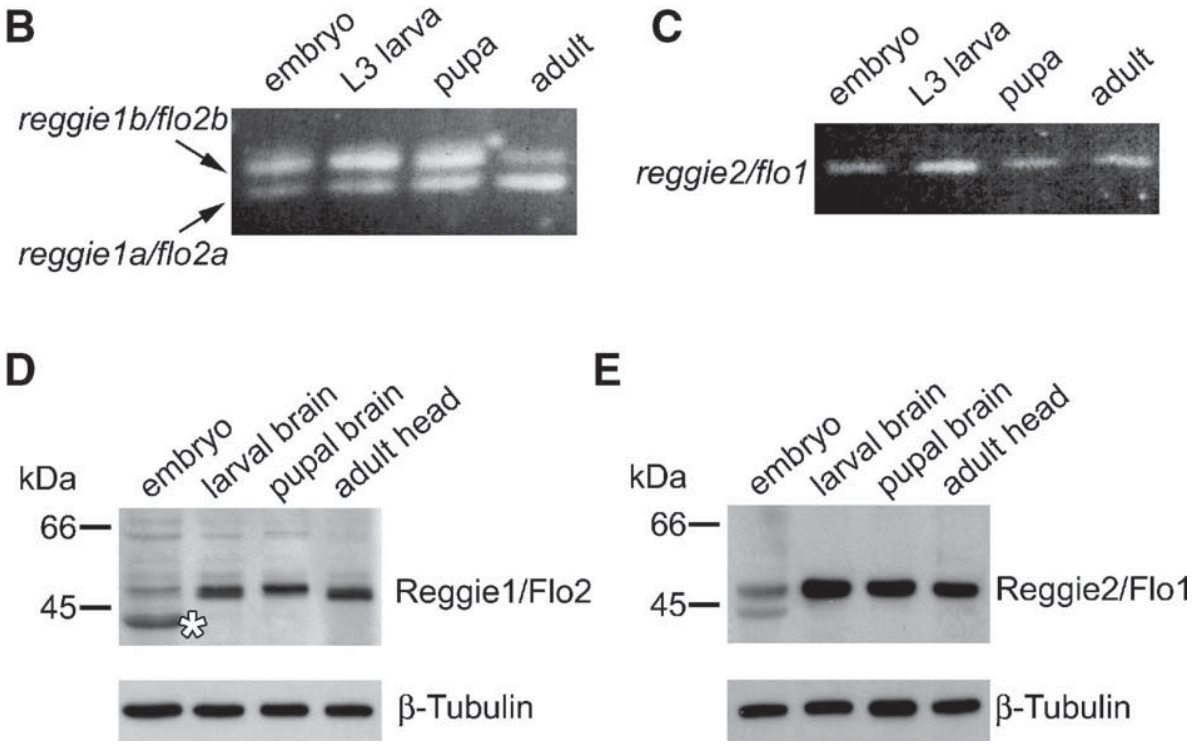

Fig. 1. (A) Schematic representation of the Drosophila reggiel/flo2 locus. The alternatively spliced Drosophila specific exon is marked. The reggiela/flo2a transcript (i.e. the isoform without the differentially spliced exon) is represented by the BDGP cDNA LD02571 and the reggielb/flolb transcript (containing the differentially spliced exon) by the BDGP cDNA LD07095. The amino acid sequence of the Drosophila specific exon is shown below the scheme. The size of exons and introns is indicated. (B, C) RT-PCR using primers specific for reggiel/flo2 and reggie2/flol, respectively, shows mRNA expression during all developmental stages. $(\mathrm{D}, \mathrm{E})$ Western blotting analysis shows the presence of a protein corresponding to the expected molecular weight of Reggie/Flotillin (47 $\mathrm{kDa}$ ) during all developmental stages. The $44 \mathrm{kDa}$ band $\left(^{*}\right)$ seen in embryo lysates is due to unspecific staining of abundant yolk proteins. The PVDF membrane was stripped and reprobed with an antibody against $\beta$-Tubulin to obtain a measure for protein concentration. The relative intensities of Reggie/ Flotillin bands in embryos are less strong than at later developmental stages where the stronger bands reflect the enrichment of Reggie/Flotillin proteins in brain and head lysates.

Reggie2/Flo1. To obtain mutants for either Reggie2/Flo1 or Reggie1/Flo2, we made use of the ongoing Berkeley Drosophila Genome Project Gene Disruption Project (Bellen et al., 2004; http://flypush.imgen.bcm.tmc.edu/pscreen). Several homozygous viable transposon insertion lines were identified. Of these, line KG00210 carries a P element insertion in exon 5 of the reggiel/ flo2 gene. To ascertain whether reggiel/flo2 gene expression is affected by this P element, we performed an RT PCR analysis on isolated RNA from adult fly heads. No reggie1/flo 2 mRNA could be detected in mutant flies (Fig. 3A). Interestingly, however, the $\mathrm{P}$ element mutant turned out to be not only deficient for the corresponding Reggie1/Flo2 translation product, but also for the paralogous Reggie2/Flo1 protein (Figs. 3B, C), whereas the reggie2/flo1 mRNA was still detectable. Reggie2/Flo1 protein levels were downregulated to trace amounts as judged by Western blot analyses (Fig. 3C). Surprisingly, however, homozygous mutants displayed no obvious external morphological phenotype. Furthermore, no structural defects in the embryonic nervous system could be detected using immunofluorescence with the neuronal markers mab 22C10 (anti Futsch) and mab 1D4 (anti FasII). The inner and the outer optic chiasms of the optic lobes, where Reggies/ Flotillins are most strongly expressed (Figs. 2E, F), also showed no obvious defects, as judged by examination of horizontal paraffin sections of mutant adult fly heads (Fig. 3D). In these sections, the central brain including the mushroom bodies and the central complex was also undistinguishable from wild type. Viability, fertility, behavior and overall activity of the mutant flies showed no apparent abnormalities.

Reggies/Flotillins are constituents of Drosophila DRM domains/lipid rafts

In order to establish the membrane association and partitioning of Reggies/Flotillins, membranes isolated from Drosophila embryos were subjected to isopycnic centrifugation on either sucrose or Optiprep density gradients of lower osmolarity after detergent extraction with Triton X 100. Both Reggies/Flotillins are present in the Triton X 100 insoluble DRM fractions of wild type embryos (Fig. 4A). These fractions also contain Fasciclin 1, a GPI linked protein that identifies the lipid raft fractions in Drosophila 

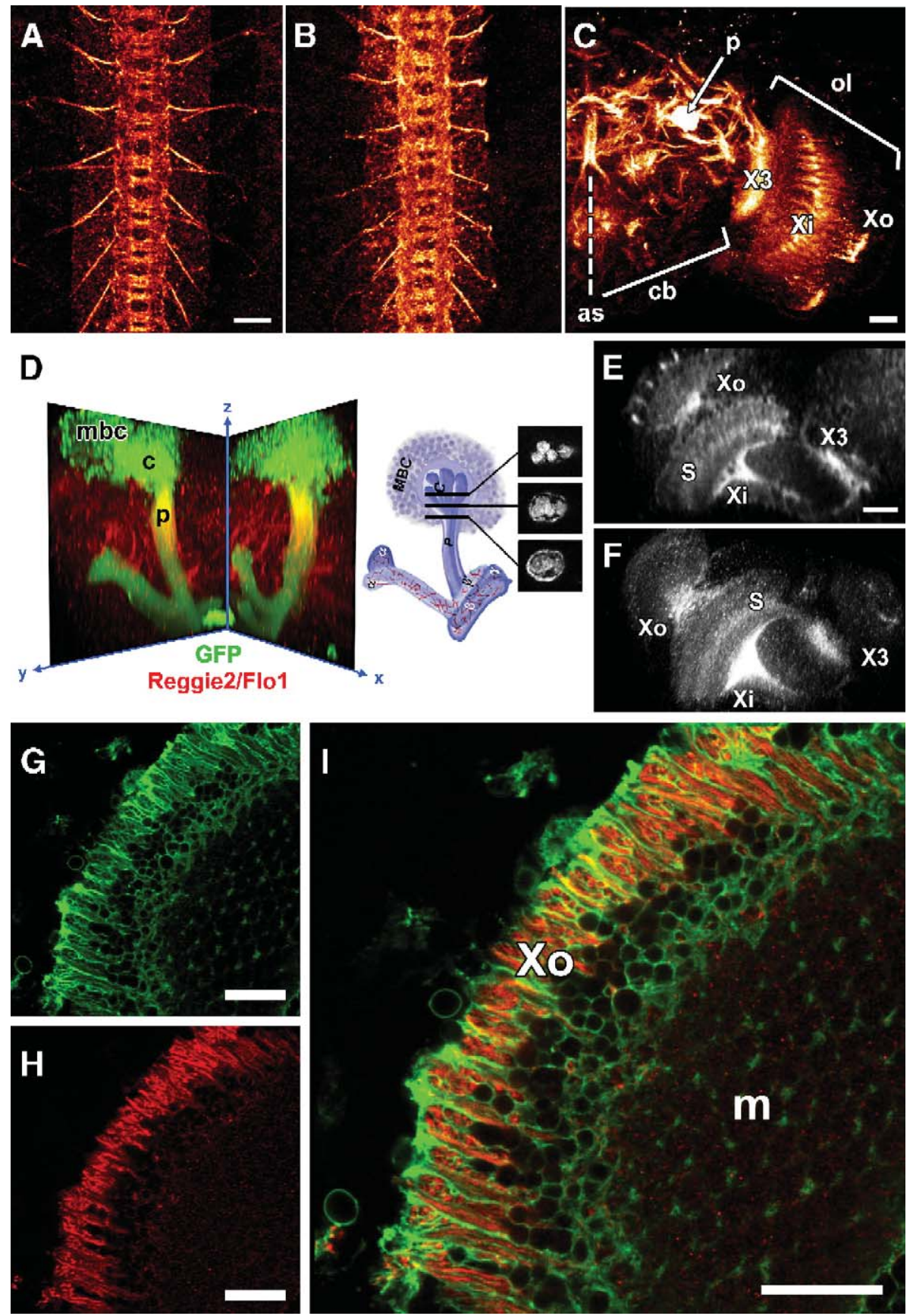

Fig. 2. Reggie/Flotillin immunostaining in the Drosophila nervous system. (A, B) In stage 16 embryos, the stereotypical pattern of longitudinal tracts and commissures is labeled with antibodies against Reggie1/Flo2 (A) and Reggie2/Flo1 (B), respectively. (C) Frontal view of the right hemisphere of an adult brain, stained with an antibody against Reggie2/Flo1. (D) Adult mushroom body expressing membrane-targeted GFP (OK107-GAL4; UAS-mCD8-GFP) and labeled with anti-Reggie2/Flo1 antibodies (red). Overlapping areas appear in yellow. Two orthogonal projection views are shown (left). Cartoon of a mushroom body (Davis, 2001) with three cross-sectional views depicted to the right showing Reggie2/Flo1 immunoreactivity at the level of the root of the peduncle (right). (E, F) Horizontal view of optic lobes in adult flies stained with antibodies against Reggie1/Flo2 (E) and Reggie2/Flo1 (F), respectively. Reggie/Flotillin immunoreactivity is strongest in the optic chiasms where axon bundles cross between the different neuropils. s, serpentine layer of the medulla; ( $\mathrm{G}$ I) Reggie/ Flotillin is expressed in neurons. The outer optic chiasm of a repo-GAL4:UAS-mCD8-GFP adult brain is shown. Glial cells are marked with GFP in green (G, I), Reggie1/Flo2 immunoreactivity is shown in red (H, I). Note that little overlap is detectable in the merged images (yellow, I). as, axis of symmetry; c, calyx; $\mathrm{cb}$, central brain; m, medulla; mbc, mushroom body cortex; ol, optic lobe; p, peduncle of the mushroom body; Xo, outer optic chiasm; Xi, inner optic chiasm; $\mathrm{X} 3$, connection between lobula and central brain. Scale bars, $20 \mu \mathrm{m}$.

(Rietveld et al., 1999) but lacks $\mathrm{Na}^{+} / \mathrm{K}^{+}$ATPase, a marker for non raft fractions (Chamberlain, 2004). Recently, Drosophila Wnt 1 (Wingless) was shown to be recruited to lipid rafts in a cell culture overexpression paradigm (Zhai et al., 2004). Here, we show that a fraction of endogenous Wingless is present in the DRM fraction. In the Reggie/Flotillin mutant KG00210 line, the fractionation pattern of Fasciclin 1 and Wingless was unchanged, despite the complete absence of both Reggies/Flotillins (Fig. 4B). Using the Optiprep 
A

A B
B
KG00210

(reggie1/flo2 mutant)

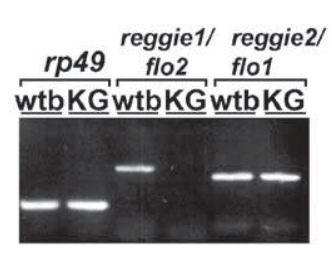

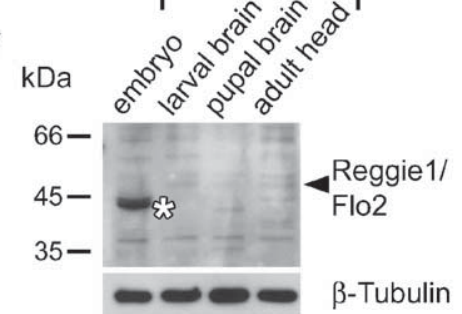

C

KG00210 (reggie1/flo2 mutant)

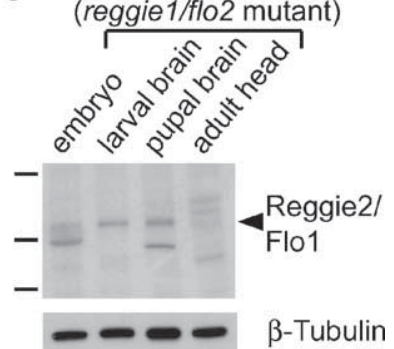

D

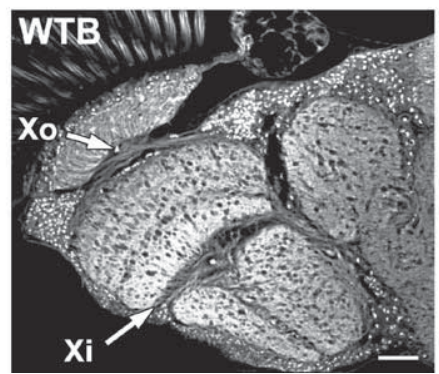

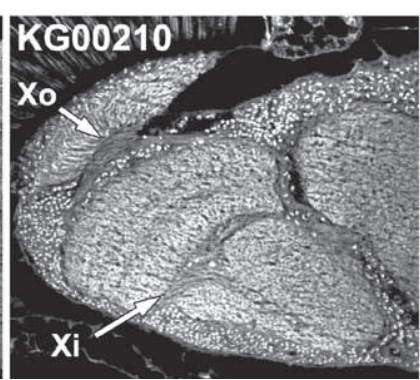

Fig. 3. Analysis of the reggiel/flo2 P-element mutant KG00210. (A) RT-PCR using specific primers reveals that no reggiel/flo2 mRNA is detected in the mutant $(\mathrm{KG})$, whereas reggie2/flo1 mRNA is present. RT-PCR with primers specific for the ribosomal protein rp49 served as control. (B, C) Western blots of lysates of reggiel/flo2 mutant flies at different developmental stages. The blots were probed with antibodies specific for Reggie1/Flo2 (B) and Reggie2/Flo1 (C), respectively as indicated (arrowheads). For loading control, the blots were stripped and reprobed with an antibody against $\beta$-Tubulin. (B) No Reggie1/ Flo2 was detected. The asterisk $\left(^{*}\right)$ marks non-specific labeling of the abundant embryonic yolk proteins and serves as an internal control (compare to wildtype data in Fig. 1D). (C) Reggie2/Flo1 is drastically reduced in the mutant (compare Fig. 1E; the wild-type data of Fig. 1E and the mutant data here represent two halves of one image of the same Western blot). Immunoreactive bands of lower molecular weight are also seen, indicative of Reggie2/Flo1 protein degradation. (D) Horizontal autofluorescent paraffin sections from adult wild-type (WTB) and reggiel/flo2 mutant (KG00210) heads. The optic lobes with the outer and inner optic chiasm are shown. No structural differences between wild type and mutant were detected. Xo, outer optic chiasm; Xi, inner optic chiasm. Scale bar, $20 \mu \mathrm{m}$.

gradient for purification (Rietveld et al., 1999), we could also show that the IgCAM Rst accumulates in the DRM fraction containing the Reggies/Flotillins (Fig. 4C).

\section{Reggie2/Flo1 protein misexpression requires Reggie1/Flo2}

The analysis of the KG00210 reggiel/flo2 null mutant unex pectedly revealed that, in addition to Reggie1/Flo2, Reggie2/Flo1 was also no longer detected on Western blots (Fig. 3C). Instead, immunoreactive bands of lower molecular weight appeared on Western blots of lysates from pupal brains and adult heads, which are not observed in lysates of wild type flies. This finding indicates that protein degradation rather than transcriptional or translational downregulation accounts for the loss of Reggie2/Flo1 (Fig. 3C). To support this hypothesis, we overexpressed both genes either alone or together using the GAL4AS system (Brand and Perrimon, 1993). If Reggie1/Flo2 were necessary for the expression or maintenance of its paralogue, ectopic expression of reggie $2 / f l o 1$

\section{A wild type}

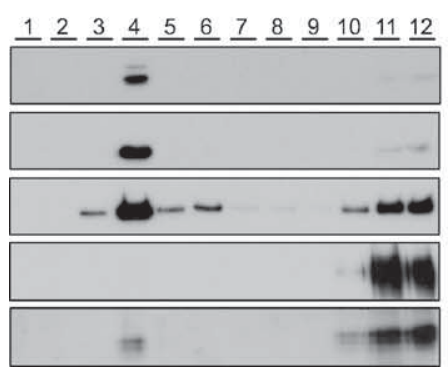

B KG00210

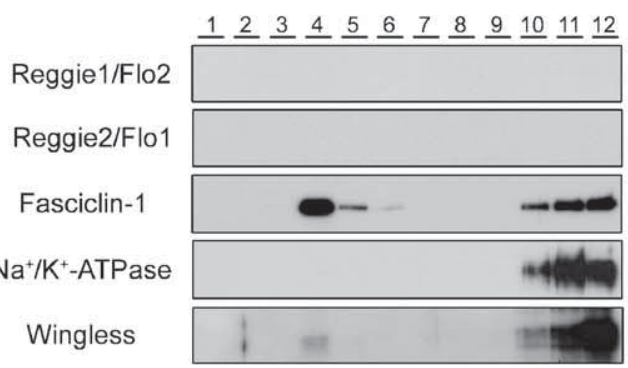

\section{C wild type}

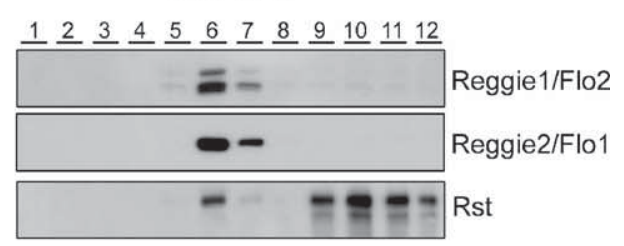

Fig. 4. Detection of Reggie1/Flo2, Reggie2/Flo1, Fasciclin-1 and Wingless in Drosophila lipid raft fractions. (A C) Embryonic membrane preparations were solubilized in $1 \%$ Triton X-100 and floated by density gradient centrifugation. (A, B) Sucrose density gradient, (C) Optiprep density gradient. Twelve fractions of equal volumes were collected from the top and subjected to Western blot analysis using the antibodies as indicated. (A, B) Detection of Fasciclin-1, a GPIlinked protein, serves to identify the fractions containing the detergent-insoluble proteins (fractions 3 6). Detection of $\mathrm{Na}^{+} / \mathrm{K}^{+}$-ATPase serves to identify the non-raft fractions. (A) Wild-type embryos. Both Reggies/Flotillins and fractions of Fasciclin-1 and Wingless are found in the DRM fractions. (B) KG00210 embryos, mutant for reggiel/flo2. No Reggie/Flotillin is detected, whereas the Fasciclin-1 and Wingless partitioning pattern is unaltered. (C) Wild-type embryos. Using Optiprep as the density medium (see Experimental methods), we were able to show that a fraction of the IgCAM Roughest (Rst) copurifies with the Reggie/Flotillin proteins. 
would conceivably not lead to a significant increase of protein levels, whereas expression of reggie1/flo2 in combination with the paralogue would. Using the da GAL4 driver line (Wodarz et al., 1995) and Western blot analysis of embryo lysates, we demonstrated that Reggie1/Flo2 can be overexpressed alone whereas Reggie2/ Flo1 requires the coexpression of its paralogue for stable expression (Fig. 5A). To confirm this finding, we used immunofluorescence analysis. The twist GAL4 line was chosen as the driver line (Baylies and Bate, 1996) since this line displays a well documented GAL4 expression pattern in the embryonic somatic mesoderm where no endogenous reggie/flotillin expression is found. Reggie1/Flo2
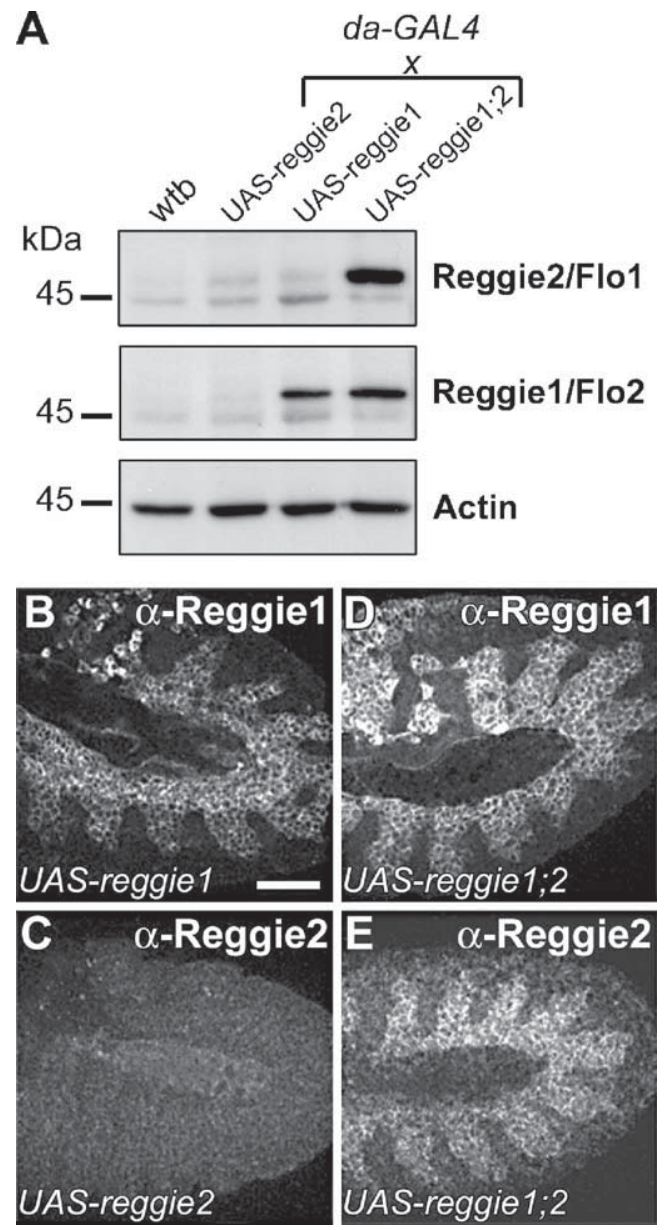

Fig. 5. Misexpression of Reggie/Flotillin in the embryo. (A) Western blot analysis of Reggie/Flotillin misexpression using da-GAL4 as a driver line. Reggies/Flotillins are detected in lysates of $1622 \mathrm{~h}$ old embryos with the antibodies indicated. Detection of Actin served as a loading control. Note that Reggie1/Flo2 is detected when misexpressed alone or together with its paralogue Reggie2/Flo1 whereas no Reggie2/Flo1 was detected when misexpressed alone. (B E) Misexpression in the embryonic mesoderm using twist-GAL4 as a driver line. All images are lateral views of the posterior part of stage 11/12 embryos. Anterior is to the left. (B) Misexpression of reggie1/flo2, (C) reggie2/flo1 or (D, E) reggie1/flo2 and reggie2/flol combined. Detection with antibodies against Reggie1/ Flo2 (B, D) and Reggie2/Flo1 (C, E), respectively. Reggie1/Flo2 immunoreactivity is readily observed when the corresponding gene is expressed alone (B), whereas the presence of Reggie2/Flo1 cannot be shown when its gene is misexpressed alone (C). Only when coexpressed with Reggie1/Flo2 the presence of the Reggie2/Flo1 protein can be detected (E). Scale bar, $50 \mu \mathrm{m}$. protein was readily detected in the embryonic mesoderm following twist GAL4 induced ectopic expression of Reggie1/Flo2 (Fig. 5B). As predicted by the mutant analysis, we failed to reveal ectopic Reggie2/Flo1 in the analogous experiment using an UAS reggie2/ flol transgenic line (Fig. 5C). However, transformant flies expressing both transgenes showed ectopic protein expression of both Reggies/Flotillins (Figs. 5D, E). This confirms that Reggie1/ Flo2 is necessary for the stabilization of Reggie2/Flo1, whereas Reggie1/Flo2 does not require Reggie2/Flo1.

Reggie/Flotillin misexpression interferes with signaling processes in imaginal discs

Overexpression of either Reggie1/Flo2 or both Reggies/ Flotillins in imaginal discs using the GAL4 enhancer trap line Mz1369 revealed that excessive Reggie/Flotillin protein is detrimental for the development of the corresponding tissues and organs (Fig. 6). Overexpressing flies display compound pheno typic defects including abnormal eyes (Figs. 7 and 8), ocelli, bristles and wings (Fig. 9). Similar to the results obtained with the da GAL4 and twist GAL4 driver lines, overexpression of Reggie2/ Flo1 alone under the transcriptional control of Mz1369 GAL4 failed to result in corresponding protein accumulation and hence did not lead to phenotypic defects. The types of defects caused by Mz1369 GAL4 driven misexpression of Reggie1/Flo2 alone or in tandem with Reggie2/Flo1 were largely indistinguishable, although flies overexpressing both proteins displayed a tendency towards more pronounced defects. In the eye disc, immunofluor escent staining with an antibody against DE Cadherin (Oda et al., 1994) revealed that misexpression of Reggies/Flotillins led to severe defects comprising a variable number of cone cells and primary pigment cells per ommatidium, errors in number and positioning of the bristle complexes and mild cell sorting defects (Fig. 7B). We speculated that these defects would be reflected in a changed expression pattern of interacting cell adhesion molecules that are known to be instrumental to the development of the regular ommatidial pattern, e.g. the Ig superfamily protein Sticks and Stones (SNS) and its heterophilic binding partners Roughest (Rst) and Kin of irre (Kirre) (Galletta et al., 2004; Strunkelnberg et al., 2001). In the eye imaginal disc, these molecules are usually seen at the apical membrane of primary pigment cells (SNS) or interommatidial cells (Rst and Kirre), respectively (Figs. 7C, E, G). In the overexpression mutants, however, antibody staining of these proteins in midpupal eye discs revealed a significant and excessive accumulation of strongly immunoreactive multivesicular bodies in interommatidal cells (Figs. 7D, F, H). Double labeling with anti Kirre and anti SNS antibodies revealed that these IgCAMs were contained in the same vesicular bodies (Fig. 8). The abnormal intracellular accumulation of the cell adhesion molecules Rst, Kirre and SNS resulting from reggie/flotillin misexpression is even more remarkable considering the phenotypically wild type localization of DE Cadherin in these overexpression mutants, indicating that the overexpression selectively affects Rst, Kirre and SNS (Fig. 7B).

The severe phenotype resulting from reggie/flotillin over expression in wing imaginal discs somehow resembled a wingless overexpression phenotype (Neumann and Cohen, 1996), including blistering. Since Wingless activity was recently shown to depend on a lipid raft dependent pathway (Zhai et al., 2004), we analyzed the Wingless expression pattern in reggie/flotillin overexpressing wing imaginal discs of L3 larvae. Immunofluorescent anti Wing 


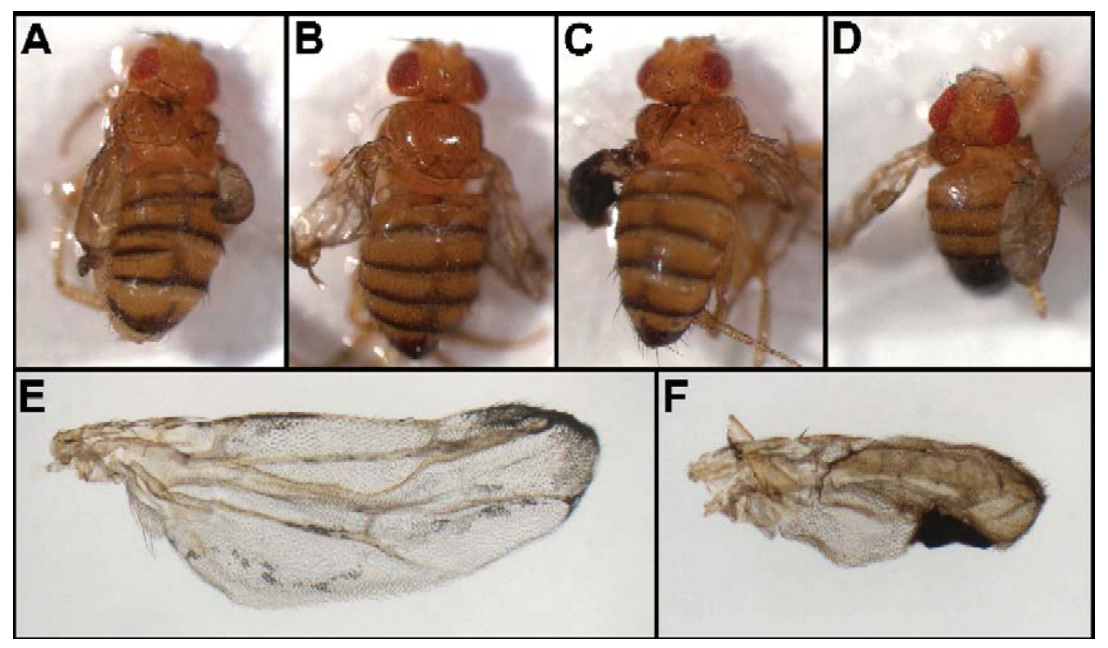

Fig. 6. Misexpression of Reggie/Flotillin in imaginal discs. (A F) Mz1369;UAS-reggie1/flo2;UAS-reggie2/flo. (A D) Adult flies show a variable phenotype affecting bristles, ocelli, eyes, wings, abdominal segments and thoracic structures consistent with underlying imaginal disc abnormalities. (E, F) Wings exhibit a highly variable but severe mutant phenotype, including blistering and melanotic cells.

less staining revealed a broadening of the Wingless immunor eactive domain in the reggielflotillin misexpression genotype, demonstrating the ability of Reggie/Flotillin to interfere with DRM domain/lipid raft based signaling processes (Fig. 9).

\section{Discussion}

The present study set out to investigate the functional genetics of a highly conserved set of proteins with a presumed pivotal role in lipid raft formation in Drosophila. We investigated the expression of two paralogous Reggie/Flotillin proteins in wild type and mutant Drosophila and analyzed the effects of both loss and gain of function on the development of the fly.

Immunofluorescence staining of stage 16 embryos revealed that Reggie1/Flo2 and Reggie2/Flo1 are, as in zebrafish (von Philips born et al., 2005), expressed in the embryonic central nervous system, where commissures were more intensely labeled than connectives (Figs. 2A, B). Postembryonically expression of both proteins is strongest in the nervous system as well and restricted to axon shafts (Fig. 2) at positions where fasciculation with other axons occurs, e.g. in the optic chiasms or at the neck of the peduncle. This supports the notion that DRM proteins provide platforms for cell adhesion and cell cell communication (Harris and Siu, 2002; Benzing, 2004, Stuermer and Plattner, 2005). It is not yet known which cell adhesion molecules are involved in the axonal fasciculation domains, but the assumption that they should be connected to Reggie/Flotillin rafts is a good starting point for their identification (Fig. 4A).

The lipid raft association of the Drosophila Reggies/Flotillins was previously reported (Galbiati et al., 1998). We show here that lipid raft formation in Drosophila is not dependent on these proteins (Fig. 4B). It is noteworthy that reported raft proteins such as Fasciclin 1 or Wingless are only fractionally recruited into the DRM/raft fraction (Rietveld et al., 1999; Zhai et al., 2004), even when Reggie/Flotillin rafts are absent (Fig. 4B). Depending on the conditions of DRM isolation, we also demonstrate the partial association of Rst with DRM/rafts (Fig. 4C). This is consistent with the view that Rst (and the other large IgCAMs) participates in a raft associated complex for recognition/adhesion. Drosophila
Rst, Kirre and SNS are the homologues of the vertebrate IgCAMs Nephs and Nephrin, which are required for the formation of specific cell contact sites in the vertebrate kidney and which are dependent on the patterned expression of the DRM/raft protein Podocin (reviewed in Benzing, 2004). Considering the complex expression pattern (Figs. 1, 2) and the evolutionarily highly conserved structure of the Reggies/Flotillins, it came as a surprise that we were unable to detect any external or internal mutant phenotypes in the KG00210 mutant, which lacks the Reggie1/Flo2 protein and in addition is depleted of the Reggie2/Flo1 protein (Fig. 3).

Although a more detailed analysis might reveal mutant phenotypes that escaped our attention, the apparent lack of a severe phenotype was unexpected. Possible explanations include compensatory upregulation of other DRM proteins with over lapping or redundant function such as stomatins, of which there appear to be three homologues in the fly genome. In addition, Western blotting experiments revealed a minor fraction of undegraded Reggie2/Flo1 protein. It is conceivable that this residual Reggie2/Flo1 protein is sufficient to suppress an apparent mutant phenotype. The absence of such mutant phenotypes for Reggie/Flotillins is reminiscent of the Caveolin 1 knock out mouse, which displays only very mild defects (Razani et al., 2001), possibly due to compensatory upregulation of other scaffolding proteins.

Evidence for posttranslational regulation of Reggies/Flotillins is provided by the reggie1/flo2 KG00210 mutant which represents a null allele at the transcriptional level. Surprisingly, in this mutant lacking Reggie1/Flo2, the Reggie2/Flo1 protein (but not its mRNA) is apparently degraded as inferred from the appearance of small Reggie2/Flo1 immunopositive bands on Western blots. This implies that Reggie2/Flo1 requires Reggie1/Flo2 for its stabilization. In fact, misexpressed Reggie2/Flo1 was only detectable when Reggie1/Flo2 was coexpressed. Several other examples for such protein protein interaction dependent stabili zation mechanisms have been published: in C. elegans, the stomatin like protein UNC 24 is needed for the stabilization of the stomatin homologue UNC 1 (Sedensky et al., 2001). In the mouse, the Caveolin 1 knock out mouse shows a significant reduction of Caveolin 2 levels (Drab et al., 2001; Razani et al., 2001). 

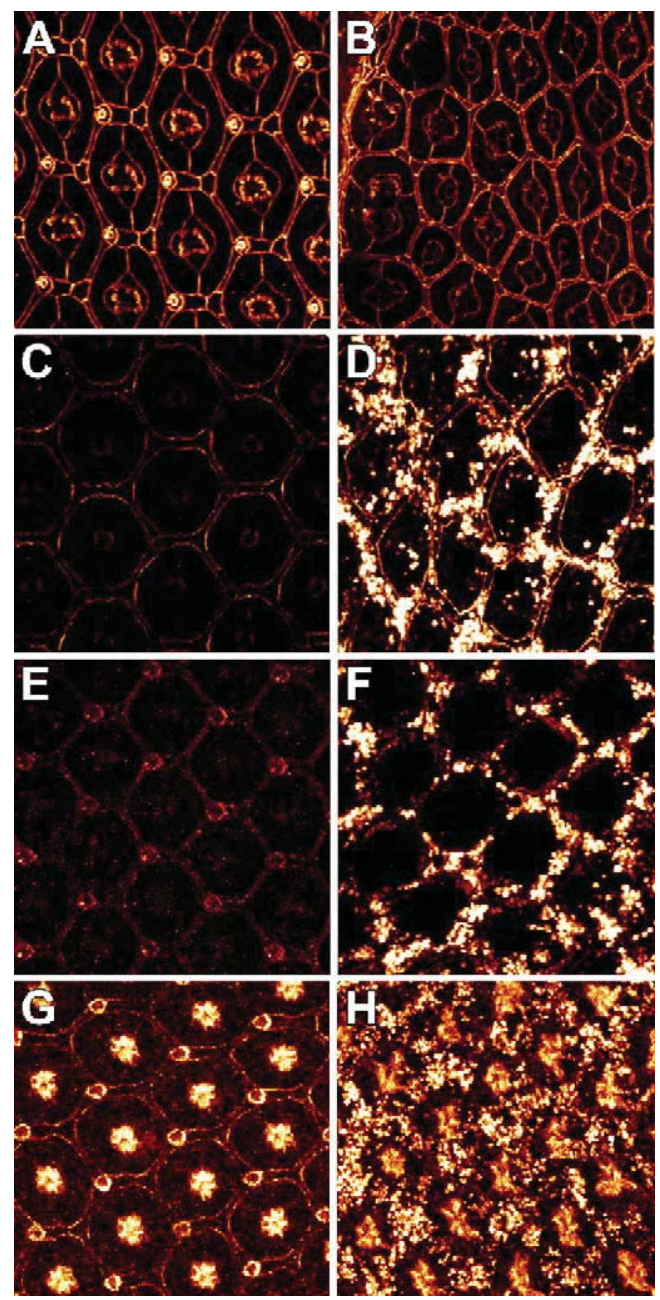

Fig. 7. Misexpression of Reggie/Flotillin in midpupal eye imaginal discs. On the left, wild-type controls are shown (A, C, E, G), on the right, the misexpression genotype Mz1369;UAS-reggiel/flo2;UAS-reggie2/flo1 (B, D, F, H). (A, B) DE-Cadherin staining reveals cell boundaries. Reggie/ Flotillin misexpression leads to a severe disturbance of the ommatidial pattern. Asterisks point to two ommatidia, the left one containing three primary pigment cells and an increased number of cone cells, while the neighboring ommatidia on the right contains only a single primary pigment cell and three cone cells instead of the normal number of four (B). (C, D) Rst, (E, F) Kirre and (G, H) Sns immunoreactivity. For all three members of the immunoglobulin superfamily, Reggie/Flotillin misexpressing eye discs contain massive accumulation of immunoreactive vesicles in interommatidial cells.
Recently, a similar interdependence was shown for mitochondrial prohibitin and prohibitone, which form membrane bound ring complexes (Berger and Yaffe, 1998; Tatsuta et al., 2005). Interestingly, these examples all concern protein pairs that, like Reggie/Flotillin, are known to reside in lipid rafts or caveolae, form multimers and thus scaffold for complex protein protein interactions (Simons and Toomre, 2000; Stuermer and Plattner, 2005). However, Drosophila Reggie1/Flo2 and Reggie2/Flo1 are not mutually dependent on each other since it is possible to stably express Reggie1/Flo2 in the absence of Reggie2/Flo1. Similarly, the Caveolin 2 knock out mouse has an almost unaltered Caveolin 1 protein content (Razani et al., 2002). The underlying mechanism for the unilateral dependence between two highly similar paralogous polypeptides remains as yet unknown. Obligate heterodimerization alone provides an insufficient explanation for the lability of one but not the other partner. Ubiquitination consensus sites or PEST sequences are ostensibly absent from Reggie/Flotillin proteins.

The biochemically defined DRM distribution of Fasciclin 1 and Wingless remained unaltered in the mutant (Fig. 4B). The lack of any visible phenotype in the mutant reminds of many reported cases where loss of function mutations affecting cell adhesion and signaling result in weak phenotypes, while ectopic and increased expression causes severe abnormalities (e.g. Thor et al., 1999; Certel et al., 2000; Torroja et al., 1999; Wills et al., 1999). Thus, ectopic expression of a gene in a particular cell type may produce phenotypes, even though it is not normally expressed in this cell.

Gain of function analysis has been successfully exploited in a screen for proteins that are involved in motor axon guidance and synaptogenesis (Kraut et al., 2001). In the absence of loss of function phenotypes, defects caused by overexpression of genes, therefore, provide useful hints to the function of the gene product (Duffy, 2002).

Such overexpression of UAS reggiel/flo2 or of UAS reggie1/ flo2; UAS reggie2/flo1 with pan neuronal GAL4 drivers lead to embryonic death, and GAL4 drivers with an expression restricted to imaginal structures caused severely deformed flies (Fig. 6). This is consistent with an interference of overexpressed Reggies/ Flotillins with morphogenesis and organogenesis. How the DRM proteins regulate these events is only vaguely understood except for the consensus that they communicate with the cytoskeleton (Baumann and Saltiel, 2001; Neumann Giesen et al., 2004; Stuermer et al., 2004).

Our results show that misexpression of the DRM/lipid raft proteins Reggie1/Flo2 and Reggie2/Flo1 in imaginal discs leads to cell differentiation defects. A possible explanation for the
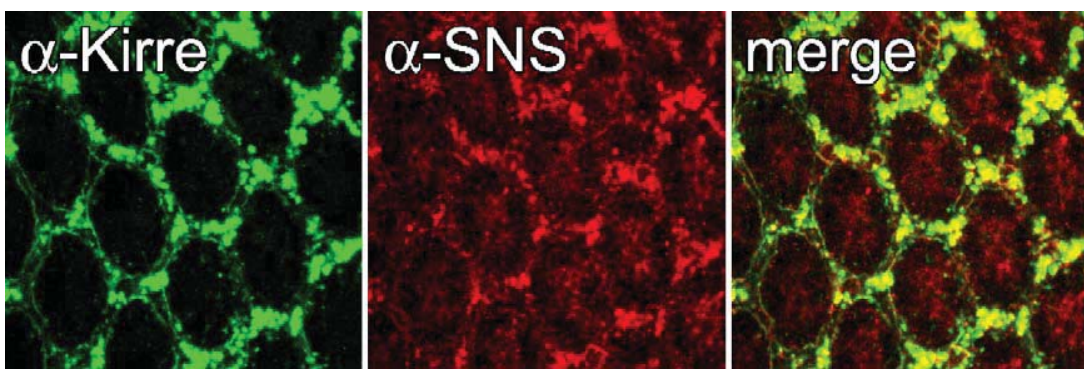

Fig. 8. Misexpression of Reggie/Flotillin in eye imaginal discs (Mz1369;UAS-reggie1/flo2;UAS-reggie2/flo1) leads to a massive accumulation of vesicular bodies in interommatidial cells that are immunoreactive for Kirre (green) and SNS (red) as seen by the yellow color in the merged image (right). 

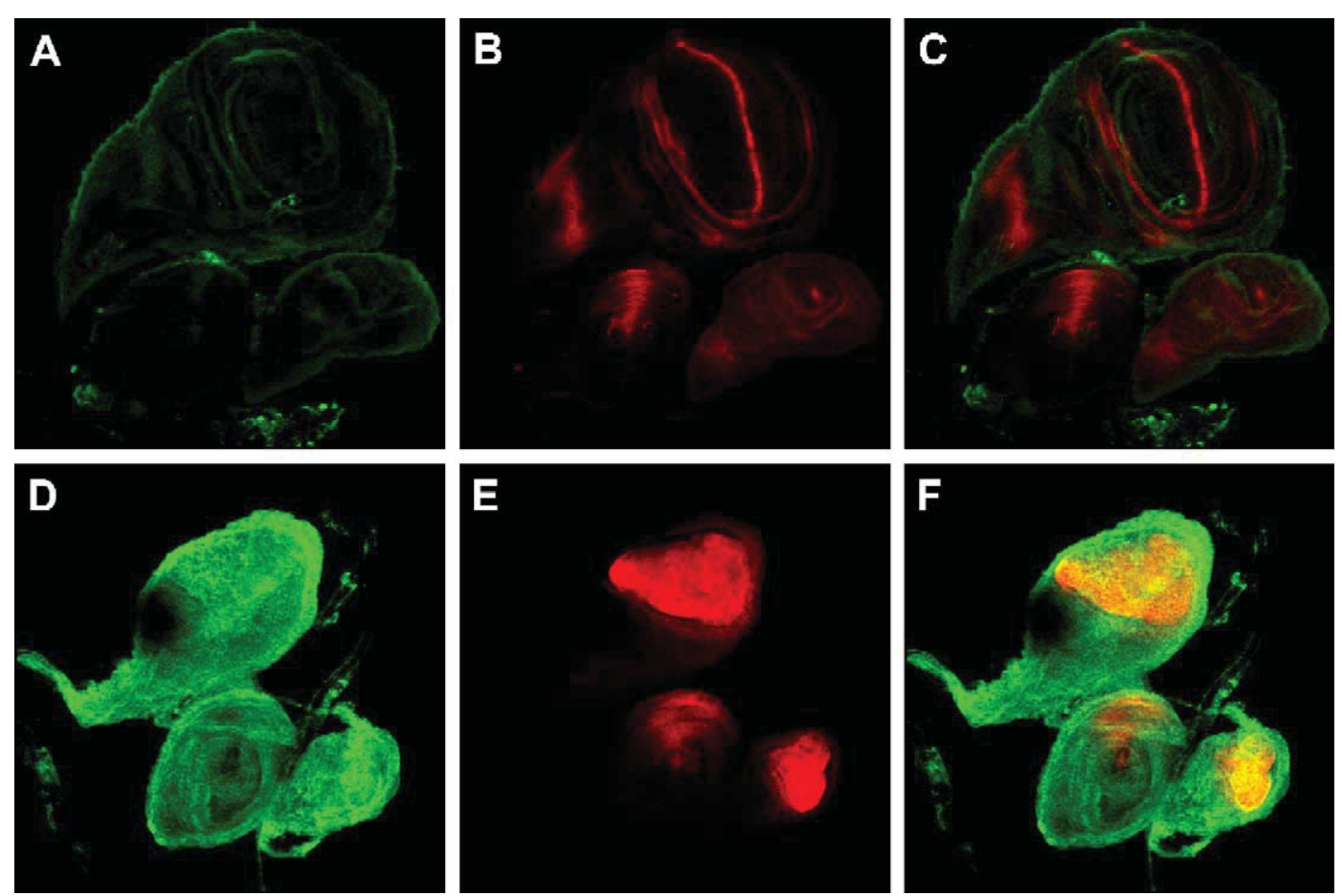

Fig. 9. Effects of misexpression of the two Reggies/Flotillins (green fluorescence) on the Wingless signal (red fluorescence) in the wing imaginal discs. (A C) Mz1369 driven misexpression of reggie2fflo1 fails to result in Reggie2/Flo1 protein overexpression (compare Fig. 5) and shows a normal Wingless immunoreactivity pattern. (D F) Mz1369 driven misexpression of reggiel/flo2 in the wing imaginal discs results in Reggie1/Flo2 overexpression and in a significant expansion of the Wingless signal.

aberrations seen in the eye imaginal discs could be provided by the specific effect on the IgCAMs of the Rst family. Rst and Kirre, as well as their ligand SNS are found inside the interommatidial cells in multivesicular bodies (Figs. 7D, F, H; Fig. 8). The proper positioning of DE Cadherin in the over expression mutant demonstrates that Reggie/Flotillin misexpres sion disturbs positioning of only a subset of adhesion proteins in the eye imaginal disc (Fig. 7B).

Rst/Kirre are expressed in founder cells during embryo muscle development, whereas their ligand SNS is expressed in fusion competent myoblasts, i.e. on opposing membranes in different cell types (Strunkelnberg et al., 2001; Bour et al., 2000). A similar scenario applies during development of the eye where Rst and Kirre are expressed in interommatidial cells, while SNS is expressed in primary pigment cells. The fact that we found Kirre/SNS immunoreactive vesicles in interommatidial cells suggests either of two scenarios. The extracellular domain of SNS may be cleaved off or shed upon binding to its ligands Rst/Kirre followed by receptor/ligand complex internalization by the interommatidial cells. Alternatively, the entire receptor/ligand complex comprising both transmembranous partners Rst/Kirre and SNS may be internalized without cleavage (Fig. 8). A conceivably similar mechanism for the internalization of a transmembrane ligand is known from the internalization of Bride of sevenless/Sevenless complexes into the R7 cell during photoreceptor development (Cagan et al., 1992). Since intra cellular vesicles containing the aforementioned IgCAMs are also seen in developing wild type eyes, albeit to a much lesser extent, it is intriguing to speculate that the normal pathway of Rst/ Kirre SNS receptor/ligand internalization is controlled by a lipid raft dependent mechanism. Massive overexpression of the Reggie/Flotillin lipid raft proteins may promote this internal ization process. Flotillin lipid rafts in vertebrates have already been implicated in phagocytotic processes (Bared et al., 2004), and one model for the internalization of transmembrane receptor/ ligand complexes is based on receptor mediated phagocytosis (Cagan et al., 1992). Further analyses are required to determine the influence of Reggie/Flotillin on membrane internalization in normal flies.

In the wing disc, Reggie/Flotillin misexpression leads to an enlargement of the Wingless $(\mathrm{Wg}$ ) expression domain (Fig. 9) and consequently to abnormal wings (Fig. 6). Wg is a secreted signaling molecule which acts as a morphogen in the Drosophila wing imaginal disc. $\mathrm{Wg}$ is normally produced along the dorso ventral border of the wing disc, and it has been suggested that membrane exovesicles termed argosomes provide a vehicle for the movement of the $\mathrm{Wg}$ protein across cells (Greco et al., 2001). Lipid rafts are likely to be involved in the formation of argosomes (Vincent and Magee, 2002) and other forms of unconventional release such as lipid bodies (Reuter et al., 2004). Recently, the lipid raft association of $\mathrm{Wg}$ before secretion was shown (Zhai et al., 2004). Argosomes resemble exosomes, and Reggie/Flotillin has been shown to be present on the surface of exosomes, but also in association with lysosomes and lipid bodies of various vertebrate cell types in culture (De Gassard et al., 2003). In this context, the severe wing phenotype caused by Reggie/Flotillin overexpression in wing imaginal discs could be the result of an increased release of $\mathrm{Wg}$ loaded argosomes resulting in abnormal dorso ventral patterning. 


\section{Experimental methods}

Fly strains and conditions of culture

Stocks were maintained at $25^{\circ} \mathrm{C}$ on standard cornmeal molasses agar food. Staging of embryos was performed according to Campos Ortega and Hartenstein (1997). Stocks used in this study were: wild type Berlin, UAS reggie1, UAS reggie2, UAS reggie1; UAS reggie2, UAS $m C D 8$ GFP (Lee et al., 1999; Bloo mington Stock Center), yellow white, KG00210 (kindly provided by Dr. A. Spradling, HHMI/Carnegie Institute, Baltimore, MD; in the meantime available from Bloomington Stock Center), OK107 GAL4 (Connolly et al., 1996; Bloomington Stock Center), repo GAL4 (kindly provided by Dr. A. Giangrande, IBMC CNRS, Strasbourg, France), twist GAL4 (Baylies and Bate, 1996), da GAL4 (Wodarz et al., 1995) and Mz1369 GAL4 (obtained from G. Technau, University of Mainz, Germany).

To obtain UAS reggiel and UAS reggie2 fly strains, the BDGP cDNAs LD02571 (i.e. the isoform without the differentially spliced exon) and CK02126, respectively, were subcloned into the pUAST vector, and yellow white flies were transformed with the resulting plasmid (Brand and Perrimon, 1993). In order to overexpress both Reggies/Flotillins in parallel, doubly homozygous flies with the genotype $y w$; $U A S$ reggie $1 A S$ reggie 1 ; UAS reggie $2 A S$ reggie 2 were generated using standard genetic crosses.

\section{Immunohistochemistry and microscopy}

Immunohistochemistry was performed as previously described (Hiesinger et al., 1999; Strunkelnberg et al., 2001). For Western blotting and immunostaining, we used antibodies generated against recombinant goldfish Reggies expressed in bacteria, which were shown to recognize epitope tagged bacterially expressed Droso phila Reggies/Flotillins (data not shown). Antibodies and dilutions used were: anti goldfish Reggie2 (R168, 1:1), anti goldfish Reggie1 (R722, 1:500 1:1000), anti Roughest (24A5; 1:20), anti DE Cadherin (DCAD2; 1:100), anti Kirre (126intra; 1:200), anti SNS (M2; 1:200) and anti Wingless (4D4; 1:10). The generation of anti Kirre and anti SNS antisera will be published elsewhere (Bonengel et al., in preparation). Secondary antibodies were $\mathrm{Cy} 3$ (Jackson Immuno Research; West Grove, PA), Alexa488 or Alexa568 (Molecular Probes; Eugene, OR) labeled. A Leica (Nussloch, Germany) $\mathrm{TCS}^{4 \mathrm{D}}$ confocal microscope equipped with an $\mathrm{ArKr}$ laser was used for data acquisition. Data were processed using Amira software (Indeed, Berlin, Germany) and Adobe Photoshop (Adobe, San Jose, CA).

\section{RT PCR}

Total RNA from embryos, 3rd instar larvae, pupae and adults was isolated using Qiagen RNeasy (Qiagen, Hilden, Germany) or Trizol (Invitrogen, Karlsruhe, Germany), according to the manu facturer's instructions. Reverse transcription was carried out with Superscript II reverse transcriptase (Invitrogen, Karlsruhe, Ger many) as described by the manufacturer. First strand cDNA was used as a template in PCR reactions using Taq polymerase (Amersham Biosciences, Freiburg, Germany) and the following primer pairs specific for reggiel/flo2 (Fig. 1: reg1forward1 $5^{\prime}$ AACCGATGTCCAGCGACTGT 3' and reg1reverse $15^{\prime}$ GGAATTGCTCGCTGGCAGTG 3'; Fig. 3: reg1forward2 5' AAGTAGAGGCGACGAGGAACGACTCA $3^{\prime}$ and reg1reverse2
5' AGGCCAGGTACTGCACATCATCGTAG 3'), reggie2/flo 1 (Fig. 1: reg2forward1 5' CCGCACGCTTCCTCAACGAT 3' and reg2reverse 1 5' TCCARGACCACGCGCTGCTT 3'; Fig. 3: reg2forward2 $5^{\prime}$ AACAAGGCTACCTGTGGATCGGATAA $3^{\prime}$ and reg2reverse $25^{\prime}$ GATGTGGTTGATCTCTGCCTCTGATT $3^{\prime}$ ) and rp49 (rp49forward 5' GACTTCATCCGCCACCAGTGC 3' and rp49reverse $5^{\prime}$ CACCAGGAACTTCTTGAATCCG $3^{\prime}$ ). PCR conditions were: $94^{\circ} \mathrm{C}$ for 4 min followed by 40 cycles at $94^{\circ} \mathrm{C}$ for 1 min, annealing for $1 \mathrm{~min}$ and $72^{\circ} \mathrm{C}$ for $1 \mathrm{~min}$ and finally $72^{\circ} \mathrm{C}$ for 5 min. Annealing temperatures were $55^{\circ} \mathrm{C}$ for reg 1 forward $1 /$ reverse 1 , $63^{\circ} \mathrm{C}$ for reg1 forward $2 /$ reverse $2,60^{\circ} \mathrm{C}$ for reg2forward $1 /$ reverse 1 , $65^{\circ} \mathrm{C}$ for reg2forward $2 /$ reverse 2 and $59^{\circ} \mathrm{C}$ for $\mathrm{rp} 49$ forward/reverse.

Isolation of detergent insoluble membrane fractions from embryos

\section{Preparation of Drosophila embryonic membranes}

Flies were allowed to lay eggs on apple juice agar supplied with fresh yeast for $14 \mathrm{~h}$. After an additional $6 \mathrm{~h}$ of incubation, embryos were collected into a wire mesh bottom container. Embryos were washed with $0.9 \% \mathrm{NaCl}+0.1 \%$ Triton $\mathrm{X} 100$ to remove debris and yeast before being dechorionated in $6 \% \mathrm{NaClO}$ in PBS. Dechorio nated embryos were washed with water, collected into $2 \mathrm{ml}$ tubes and stored at $-80^{\circ} \mathrm{C} .1 \mathrm{mg}$ of frozen embryos was resuspended in 2 $\mathrm{ml}$ TNE buffer (100 mM Tris ( $\mathrm{pH} 7.5), 150 \mathrm{mM} \mathrm{NaCl}$ and $0.2 \mathrm{mM}$ EDTA) containing $0.3 \mathrm{M}$ sucrose, $0.1 \mathrm{mM}$ DTT, $1 \mathrm{mM}$ phenyl methyl sulfonyl fluoride (PMSF) and protease inhibitor cocktail (BD Pharmingen, San Diego, CA). Embryos were homogenized using a Wheaton homogenizer. The embryo homogenate was centrifuged at $4500 \mathrm{rpm}$ for $10 \mathrm{~min}$ at $4^{\circ} \mathrm{C}$ to remove debris and to pellet nuclei (SS34 rotor). The post nuclear supernatant was transferred to a SW28 tube, adjusted to $1.4 \mathrm{M}$ sucrose by addition of $14 \mathrm{ml}$ of $1.55 \mathrm{M}$ sucrose in TNE buffer and overlayed with $11 \mathrm{ml}$ of $1.22 \mathrm{M}$ sucrose in TNE buffer and $9 \mathrm{ml}$ of $0.1 \mathrm{M}$ sucrose in TNE buffer and then centrifuged for $4 \mathrm{~h}$ at $24,500 \mathrm{rpm}$ at $4{ }^{\circ} \mathrm{C}$. Membranes were observed floating above the $1.22 \mathrm{M} / 0.1 \mathrm{M}$ sucrose interphase. This fraction $(2 \mathrm{ml})$ was collected, diluted three fold in TNE buffer and pelleted for $30 \mathrm{~min}$ at $17,500 \mathrm{rpm}\left(\mathrm{SS} 34\right.$ rotor) at $4^{\circ} \mathrm{C}$. The membrane fraction was washed once with $3 \mathrm{ml} \mathrm{TNE}$ buffer.

\section{Purification of detergent insoluble membranes using a sucrose gradient}

The membrane pellet was resuspended in $500 \mu \mathrm{TNE}$ buffer and transferred to a SW41 tube. An equal volume of cold $2 \%$ Triton X 100 in TNE buffer was added, and the membranes were solubilized on ice for $30 \mathrm{~min}$. One $\mathrm{ml} 85 \%$ sucrose in TNE buffer $(\mathrm{w} / \mathrm{v})$ was added and overlayed with $6 \mathrm{ml}$ of $35 \%$ sucrose in TNE buffer and $3.5 \mathrm{ml} \mathrm{5 \%}$ sucrose in TNE buffer. The gradient was centrifuged overnight at $35,000 \mathrm{rpm}$ at $4{ }^{\circ} \mathrm{C}$ (SW41 rotor). Twelve fractions were collected by aspiration from the top and analyzed SDS polyacrylamide gel electrophoresis and Western blotting (Figs. 4A, B).

\section{Purification of detergent insoluble membranes using an Optiprep gradient}

The membrane fraction derived by differential centrifugation was resuspended in $200 \mu \mathrm{l}$ TNE buffer. An equal volume of cold $2 \%$ Triton X 100 in TNE buffer was added, and the membranes were solubilized on ice for $30 \mathrm{~min}$. Following solubilization, 800 $\mu$ Optiprep (Axis shield, Oslo, Norway) was added to achieve a final concentration of $40 \%$ Optiprep. $1 \mathrm{ml}$ of the suspension was transferred to SW65 tubes and overlayed with $1 \mathrm{ml}$ of 30, 20 and 
5\% Optiprep, respectively, and finally with $1 \mathrm{ml}$ of TNE buffer. The gradient was centrifuged for $6 \mathrm{~h}$ at 46,900 rpm (SW41 rotor) at $4{ }^{\circ} \mathrm{C}$. Fractions were collected and analyzed as described above (Fig. 4C).

\section{Fly lysates}

Dechorionated embryos, larval and pupal brains and adult heads were homogenized in $1 \times$ SDS electrophoresis sample buffer and boiled for $5 \mathrm{~min}$. An aliquot corresponding to three heads or brains, respectively, was loaded per lane of a SDS polyacrylamide gel.

\section{Western blotting}

The sucrose gradient fractions and fly head lysates were fractionated on $10 \%$ SDS polyacrylamide gels and blotted onto Hybond P membranes (Amersham Biosciences, Freiburg, Ger many) according to standard methods (Ausubel et al., 1994). Non specific binding sites were blocked with $3 \%$ skim milk powder (Fluka, Buchs, Switzerland) in PBST (PBS containing 0.1\% Tween $(\mathrm{v} / \mathrm{v})$ ) for $30 \mathrm{~min}$ at room temperature followed by incubation with the primary antibody for $1 \mathrm{~h}$ at room temperature and washed four times with PBST for 10 min each. HRP conjugated secondary antibodies (Sigma) were used at the recommended dilution in PBST and incubated for $45 \mathrm{~min}$ at room temperature. Antigen antibody complexes were detected by chemiluminescence using a commercial ECL kit (Amersham Biosciences, Freiburg, Germany). Primary antibodies and the dilutions used were: R722 (anti goldfish Reggie1; 1:1000), R168 (anti goldfish Reggie2; 1:10), 21D11 (anti Roughest, 1:40), E7 (anti $\beta$ Tubulin, 1:250), JLA20 (anti Actin; 1:200), f5H7 (anti Fasciclin 1, 1:500; kindly provided by Dr. M. Hortsch, Univ. of Michigan, Ann Arbor, MI), 1B2 (anti $\mathrm{Na}^{+} / \mathrm{K}^{+}$ATPase, 1:8000), 4D4 (anti Wingless; 1:50) and 21D11 (anti Roughest; 1:40).

\section{Paraffin sections}

Horizontal paraffin sections of adult fly heads were prepared as described by Jäger and Fischbach (1987) and viewed with a confocal microscope.

\section{Acknowledgments}

We thank Drs. A. Spradling, A. Giangrande, M. Hortsch and the Bloomington Stock Center for supplying fly strains and antibodies for this study. The E7, JLA20, DCAD2 and 4D4 monoclonal antibodies were obtained from the Developmental Studies Hybridoma Bank developed under the auspices of the NICHD and maintained by The University of Iowa, Department of Biological Sciences, Iowa City, IA 52242. We also thank S. Vishnu, A. Hertenstein, Dr. Edward Málaga Trillo and W. Michalke for discussion and commenting on the manuscript and M. Böhler and W. Brinkmann for the maintenance of reagents and fly stocks and $\mathrm{Ch}$. Reiter for starting the project in our laboratory. Our work was supported by the DFG: SFB 505 (to K. F. F.) and TR SFB 11 (to C.A.O.S). H.G. de C. was the recipient of a Fulbright Senior Fellowship during a part of this study and was supported by a grant from the Friends of the Cancer Research Center of Hawaii.

\section{References}

Ausubel, F.M., Brent, R., Kingston, R.E., Moore, D.D., Seidman, J.G., Smith, J.A., Struhl, K., 1994. Current Protocols in Molecular Biology. John Wiley \& Sons, Inc.

Bared, S.M., Buechler, C., Boettcher, A., Dayoub, R., Sigruener, A., Grandl, M., Rudolph, C., Dada, A., Schmitz, G., 2004. Association of ABCA1 with Syntaxin 13 and Flotillin-1 and enhanced phagocytosis in tangier cells. Mol. Biol. Cell 15, 53995407.

Baumann, C.A., Saltiel, A.R., 2001. Spatial compartmentalization of signal transduction in insulin action. Bioessays 23, 215222.

Baylies, M.K., Bate, M., 1996. twist: a myogenic switch in Drosophila. Science 272, 14811484.

Bellen, H.J., Levis, R.W., Liao, G., He, Y., Carlson, J.W., Tsang, G., EvansHolm, M., Hiesinger, P.R., Schulze, K.L., Rubin, G.M., Hoskins, R.A., Spradling, A.C., 2004. The BDGP gene disruption project: single transposon insertions associated with $40 \%$ of Drosophila genes. Genetics 167, 761781 .

Benzing, T., 2004. Signaling at the slit diaphragm. J. Am. Soc. Nephrol. 15, 13821391.

Berger, K.H., Yaffe, M.P., 1998. Prohibitin family members interact genetically with mitochondrial inheritance components in Saccharomyces cerevisiae. Mol. Cell. Biol. 18, 40434052.

Bickel, P.E., Scherer, P.E., Schnitzer, J.E., Oh, P., Lisanti, M.P., Lodish, H.F., 1997. Flotillin and epidermal surface antigen define a new family of caveolae-associated integral membrane proteins. J. Biol. Chem. 272, 1379313802.

Bour, B.A., Chakravarti, M., West, J.M., Abmayr, S.M., 2000. Drosophila SNS, a member of the immunoglobulin superfamily that is essential for myoblast fusion. Genes Dev. 14, 14981511.

Boute, N., Gribouval, O., Roselli, S., Benessy, F., Lee, H., Fuchshuber, A., Dahan, K., Gubler, M.C., Niaudet, P., Antignac, C., 2000. NPHS2, encoding the glomerular protein podocin, is mutated in autosomal recessive steroid-resistant nephrotic syndrome. Nat. Genet. 24, 349354 .

Brand, A.H., Perrimon, N., 1993. Targeted gene expression as a means of altering cell fates and generating dominant phenotypes. Development 118, 401415.

Cagan, R.L., Kramer, H., Hart, A.C., Zipursky, S.L., 1992. The bride of sevenless and sevenless interaction: internalization of a transmembrane ligand. Cell 69, 393399.

Campos-Ortega, J.A., Hartenstein, V., 1997. The Embryonic Development of Drosophila Melanogaster, 2nd ed. Springer Verlag, Berlin, Germany.

Certel, S.J., Clyne, P.J., Carlson, J.R., Johnson, W.A., 2000. Regulation of central neuron synaptic targeting by the Drosophila POU protein, Acj6. Development 127, 23952405.

Chamberlain, L.H., 2004. Detergents as tools for the purification and classification of lipid rafts. FEBS Lett. 559, 15.

Connolly, J.B., Roberts, I.J., Armstrong, J.D., Kaiser, K., Forte, M., Tully, T., O'Kane, C.J., 1996. Associative learning disrupted by impaired Gs signaling in Drosophila mushroom bodies. Science 274, 21042107.

Davis, R.L., 2001. Mushroom bodies, $\mathrm{Ca}(2+)$ oscillations, and the memory gene amnesiac. Neuron 30, 653656.

De Gassard, A., Geminard, C., Fevrier, B., Raposo, G., Vidal, M., 2003. Lipid raft-associated protein sorting in exosomes. Blood 102, 43364344.

Deininger, S.O., Rajendran, L., Lottspeich, F., Przybylski, M., Illges, H., Stuermer, C.A., Reuter, A., 2003. Identification of teleost Thy-1 and association with the microdomain/lipid raft Reggie proteins in regenerating CNS axons. Mol. Cell. Neurosci. 22, 544554.

Drab, M., Verkade, P., Elger, M., Kasper, M., Lohn, M., Lauterbach, B., Menne, J., Lindschau, C., Mende, F., Luft, F.C., Schedl, A., Haller, H., Kurzchalia, T.V., 2001. Loss of caveolae, vascular dysfunction, and pulmonary defects in caveolin-1 gene-disrupted mice. Science 293, 24492452. 
Duffy, J.B., 2002. GAL4 system in Drosophila: a fly geneticist's Swiss army knife. Genesis 34, 115 .

Galbiati, F., Volonte, D., Goltz, J.S., Steele, Z., Sen, J., Jurcsak, J., Stein, D., Stevens, L., Lisanti, M.P., 1998. Identification, sequence and developmental expression of invertebrate flotillins from Drosophila melanogaster. Gene 210, 229237.

Galletta, B.J., Chakravarti, M., Banerjee, R., Abmayr, S.M., 2004. SNS: adhesive properties, localization requirements and ectodomain dependence in S2 cells and embryonic myoblasts. Mech. Dev. 121, 14551468

Golub, T., Wacha, S., Caroni, P., 2004. Spatial and temporal control of signaling through lipid rafts. Curr. Opin. Neurobiol. 14, 542550.

Greco, V., Hannus, M., Eaton, S., 2001. Argosomes: a potential vehicle for the spread of morphogens through epithelia. Cell 106, 633645.

Harris, T.J., Siu, C.H., 2002. Reciprocal raft receptor interactions and the assembly of adhesion complexes. Bioessays 24, 9961003.

Helms, J.B., Zurzolo, C., 2004. Lipids as targeting signals: lipid rafts and intracellular trafficking. Traffic. 5, 247254.

Hiesinger, P.R., Reiter, C., Schau, H., Fischbach, K.F., 1999. Neuropil pattern formation and regulation of cell adhesion molecules in Drosophila optic lobe development depend on synaptobrevin. J. Neurosci. 19,75487556

Ito, K., Awano, W., Suzuki, K., Hiromi, Y., Yamamoto, D., 1997. The Drosophila mushroom body is a quadruple structure of clonal units each of which contains a virtually identical set of neurones and glial cells. Development 124, 761771

Jäger, R.J., Fischbach, K.-F., 1987. Some improvements of the HeisenbergBöhl method for mass histology on Drosophila heads. Dros. Inf. Service 66, 162165.

Kioka, N., Ueda, K., Amachi, T., 2002. Vinexin, CAP/ponsin, ArgBP2: a novel adaptor protein family regulating cytoskeletal organization and signal transduction. Cell Struct. Funct. 27, 17.

Kraut, R., Menon, K., Zinn, K., 2001. A gain-of-function screen for genes controlling motor axon guidance and synaptogenesis in Drosophila. Curr. Biol. 11, 417430.

Lang, D.M., Lommel, S., Jung, M., Ankerhold, R., Petrausch, B., Laessing, U., Wiechers, M.F., Plattner, H., Stuermer, C.A., 1998. Identification of Reggie1 and Reggie2 as plasma membrane-associated proteins which cocluster with activated GPI-anchored cell adhesion molecules in noncaveolar micropatches in neurons. J. Neurobiol. 37, 502523.

Lee, T., Lee, A., Luo, L., 1999. Development of the Drosophila mushroom bodies: sequential generation of three distinct types of neurons from a neuroblast. Development 126, 40654076.

Lopez-Casas, P.P., del Mazo, M.J., 2003. Regulation of flotillin-1 in the establishment of NIH-3T3 cell cell interactions. FEBS Lett. 555, 223228 .

Malaga-Trillo, E., Laessing, U., Lang, D.M., Meyer, A., Stuermer, C.A., 2002. Evolution of duplicated Reggie genes in zebrafish and goldfish. J. Mol. Evol. 54, 235245.

Neumann, C.J., Cohen, S.M., 1996. Distinct mitogenic and cell fate specification functions of wingless in different regions of the wing. Development 122, 17811789.

Neumann-Giesen, C., Falkenbach, B., Beicht, P., Claasen, S., Luers, G., Stuermer, C.A., Herzog, V., Tikkanen, R., 2004. Membrane and raft association of Reggie1/Flo2: role of myristoylation, palmitoylation and oligomerization and induction of filopodia by overexpression. Biochem. J. 378, 509518 .

Oda, H., Uemura, T., Harada, Y., Iwai, Y., Takeichi, M., 1994. A Drosophila homolog of cadherin associated with armadillo and essential for embryonic cell cell adhesion. Dev. Biol. 165, 716726.

Rajendran, L., Masilamani, M., Solomon, S., Tikkanen, R., Stuermer, C.A., Plattner, H., Illges, H., 2003. Asymmetric localization of Flotillins/Reggies in preassembled platforms confers inherent polarity to hematopoietic cells. Proc. Natl. Acad. Sci. U. S. A. 100, 82418246.

Razani, B., Engelman, J.A., Wang, X.B., Schubert, W., Zhang, X.L., Marks, C.B., Macaluso, F., Russell, R.G., Li, M., Pestell, R.G., Di, V.D., Hou, H., Kneitz Jr., B., Lagaud, G., Christ, G.J., Edelmann, W.,
Lisanti, M.P., 2001. Caveolin-1 null mice are viable but show evidence of hyperproliferative and vascular abnormalities. J. Biol. Chem. 276, 3812138138.

Razani, B., Wang, X.B., Engelman, J.A., Battista, M., Lagaud, G., Zhang, X.L., Kneitz, B., Hou, H., Christ Jr., G.J., Edelmann, W., Lisanti, M.P., 2002. Caveolin-2-deficient mice show evidence of severe pulmonary dysfunction without disruption of caveolae. Mol. Cell. Biol. 22, 23292344.

Reuter, A., Binkle, U., Stuermer, C.A., Plattner, H., 2004. PrPc and reggies/flotillins are contained in and released via lipid-rich vesicles in Jurkat T cells. Cell. Mol. Life Sci. 61, 20922099.

Rietveld, A., Neutz, S., Simons, K., Eaton, S., 1999. Association of steroland glycosylphosphatidylinositol-linked proteins with Drosophila raft lipid microdomains. J. Biol. Chem. 274, 1204912054.

Schulte, T., Paschke, K.A., Laessing, U., Lottspeich, F., Stuermer, C.A., 1997. Reggie-1 and Reggie-2, two cell surface proteins expressed by retinal ganglion cells during axon regeneration. Development 124, 577587.

Sedensky, M.M., Siefker, J.M., Morgan, P.G., 2001. Model organisms: new insights into ion channel and transporter function. Stomatin homologues interact in Caenorhabditis elegans. Am. J. Physiol.: Cell Physiol. 280, $\mathrm{C} 1340 \mathrm{C} 1348$

Simons, K., Toomre, D., 2000. Lipid rafts and signal transduction. Nat. Rev., Mol. Cell Biol. 1, 3139.

Strunkelnberg, M., Bonengel, B., Moda, L.M., Hertenstein, A., de Couet, H.G., Ramos, R.G., Fischbach, K.F., 2001. Rst and its paralogue Kirre act redundantly during embryonic muscle development in Drosophila. Development 128, 42294239.

Stuermer, C.A.O., Plattner, H., 2005. The lipid raft microdomain proteins reggie-1 and reggie-2 (Flotillins) are scaffolds for protein interaction and signalling. Biochem. Soc. Symp. 72, 109118.

Stuermer, C.A., Lang, D.M., Kirsch, F., Wiechers, M., Deininger, S.O., Plattner, H., 2001. Glycosylphosphatidyl inositol-anchored proteins and fyn kinase assemble in noncaveolar plasma membrane microdomains defined by Reggie1 and-2. Mol. Biol. Cell 12, 30313045.

Stuermer, C.A., Langhorst, M.F., Wiechers, M.F., Legler, D.F., Von Hanwehr, S.H., Guse, A.H., Plattner, H., 2004. PrPc capping in T cells promotes its association with the lipid raft proteins Reggie1 and Reggie2 and leads to signal transduction. FASEB J. 18, 17311733.

Tatsuta, T., Model, K., Langer, T., 2005. Formation of membrane-bound ring complexes by prohibitins in mitochondria. Mol. Biol. Cell 16, 248259 .

Thor, S., Andersson, S.G., Tomlinson, A., Thomas, J.B., 1999. A LIMhomeodomain combinatorial code for motor-neuron pathway selection. Nature 397, 7680.

Torroja, L., Packard, M., Gorczyca, M., White, K., Budnik, V., 1999. The Drosophila beta-amyloid precursor protein homolog promotes synapse differentiation at the neuromuscular junction. J. Neurosci. 19, 77937803.

Tsui-Pierchala, B.A., Encinas, M., Milbrandt, J., Johnson Jr, E.M., 2002. Lipid rafts in neuronal signaling and function. Trends Neurosci. 25, 412417.

Vincent, J.P., Magee, T., 2002. Argosomes: membrane fragments on the run. Trends Cell Biol. 12, 5760

Volonte, D., Galbiati, F., Li, S., Nishiyama, K., Okamoto, T., Lisanti, M.P., 1999. Flotillins/cavatellins are differentially expressed in cells and tissues and form a hetero-oligomeric complex with caveolins in vivo. Characterization and epitope-mapping of a novel flotillin-1 monoclonal antibody probe. J. Biol. Chem. 274, 1270212709.

von Philipsborn, A.C., Ferrer-Vaquer, A., Rivera-Milla, E., Stuermer, C.A., Malaga-Trillo, E., 2005. Restricted expression of Reggie genes and proteins during early zebrafish development. J. Comp. Neurol. 482, 257272.

Wills, Z., Bateman, J., Korey, C.A., Comer, A., Van, V.D., 1999. The tyrosine kinase $\mathrm{Abl}$ and its substrate enabled collaborate with the receptor phosphatase Dlar to control motor axon guidance. Neuron 22, 301312 . 
Wodarz, A., Hinz, U., Engelbert, M., Knust, E., 1995. Expression of crumbs confers apical character on plasma membrane domains of ectodermal epithelia of Drosophila. Cell 82, 6776.

Zajchowski, L.D., Robbins, S.M., 2002. Lipid rafts and little caves. Compartmentalized signalling in membrane microdomains. Eur. J. Biochem. 269, 737752 .
Zars, T., 2000. Behavioral functions of the insect mushroom bodies. Curr. Opin. Neurobiol. 10, 790795.

Zhai, L., Chaturvedi, D., Cumberledge, S., 2004. Drosophila wnt-1 undergoes a hydrophobic modification and is targeted to lipid rafts, a process that requires porcupine. J. Biol. Chem. 279, 3322033227. 